\title{
Current Changes in Primary Education: The issue of "different" in a primary school mathematics classroom
}

\author{
Ioannis Papadopoulos, Darina Jirotková, Jana Slezáková, \\ Esperanza López Centella
}

\begin{abstract}
In the setting of the transformation of our societies to become multicultural ones, we intend in this paper to examine situations in a mathematics classroom where respect for, and exclusion of, the 'different' co-exist. Conducting an instrumental case study, we follow two Grade 4 groups while they are solving a mathematics generalization task. We examine how the interaction that took place between the members of the teams mirrors the two faces of the same coin (i.e. the culture of the classroom) and at the same time reflects the change in the primary classroom that necessitates openness and genuine respect for the 'different'. On the one hand, we will demonstrate the dynamic of the harmony that was apparent between the members of one of the groups since the 'different' was not a barrier but a source of mathematical ideas that contributed to the solution. On the other hand, the lack of openness in the other group resulted in good opportunities for 'doing mathematics' being missed and put the self-confidence of one of its members at risk.
\end{abstract}

Keywords: classroom diversity and conflict, multicultural mathematics classroom, collaborative problem-solving

\section{INTRODUCTION}

Globalization has resulted in the gradual transformation of our societies from monocultural to multicultural ones. This poses a challenge to, among others, the school systems in each country to understand the potential of this change for the enrichment of teaching practice (Kostelecká, Hána, \& Hasman, 2017). More specifically, we would like to shift the attention to the challenge posed for the mathematics classroom. Multiculturalism acts to highlight intensively the issue of diversity, 'sameness' and 'difference', which may function as both an obstacle to, and an opportunity for, learning. Most of the research on the learning of mathematics in multicultural classrooms has highlighted language as a dominant aspect (see, for example, the work of Kaiser (2003) or the research of Møller (2001) on the problems of bilingualism). However, Alrø, Skovsmose, and Valero (2005) propose 
approaching this issue from a more communicative and social perspective, through a careful investigation of communication inside groupings while doing mathematics (Alrø, Skovsmose, \& Valero, 2010). In this setting, two classroom episodes will be presented and analyzed in this paper as we follow young pupils while they try to accomplish a mathematics generalization task. The aim was to examine the communication between pupils in a multicultural classroom in order to shed light on the following research questions:

- How might this classroom diversity enhance collaborative mathematical problem-solving?

- How might the potential conflict in collaborative problem-solving influence the problem-solving process?

\section{THEORETICAL FRAMEWORK}

\section{AND RESEARCH LITERATURE}

Given the aim of the research questions, we were led to build our theoretical framework on the notion of Landscapes of Mathematical Learning (Alrø, Skovsmose, \& Valero, 2005) and, more specifically, on two concepts relevant to the features of a learning landscape: diversity and conflict.

The notion of a Landscape of Mathematical Learning has a double meaning. On the one hand, it refers to mathematics education as a complex network of social practice with a variety of interrelated dimensions. In this sense, the notion of a 'landscape of learning' has a social dimension and must be differentiated from the notion of a 'cognitive landscape' as negotiated in the work of Šíp (2019), who approaches the term from a purely psychological perspective. On the other hand, it allows the identification of the dimensions of an empirical field to do research in (Alrø, Skovsmose, \& Valero, 2009). Nine dimensions have been identified as relevant to understanding the social complexity of a multicultural mathematics classroom: (i) pupils' foregrounds as an experienced socio-political reality, (ii) pupils' construction of identity and cultural diversities, (iii) the teacher's perspectives, opinions, and priorities of teaching, (iv) the mathematical content for classroom interaction, (v) tools or resources for learning, (vi) classroom interaction among pupils, (vii) family and parents who influence pupils' priorities, (viii) friends, who are reference groups for the pupils, and (ix) public discourses about immigrants, schooling, and multiculturalism. For the purpose of this paper, we restrict ourselves to one of them, which is the classroom interaction among pupils. The pupils are members of the classroom community and mathematical meaning-making is in essence a social product arising from and during the interactions between the members of the classroom community (Gorgorió, Planas, \& Vilella, 2002). Two concepts that interaction is related to are diversity and conflict, which will be the focus of this study.

\section{Diversity}

The meaning given to diversity in the mathematics classroom has rather 
changed in recent decades since the number of people who cross borders for a variety of reasons has increased dramatically. This has resulted in a change in classroom synthesis in terms of ethnicities and cultures, which is accompanied by a change in the diversity of pupils' ideas and learning styles (Seah \& Andersson, 2015). Very often this new situation is interpreted by the teacher as showing the need for an effort to take care of those newcomers who might struggle with mathematics in order to protect them from a feeling of failure and disengagement (Ferguson, 2009). However, another approach would be to consider how this diversity of pupils (in terms of culture or ethnicity or language), and consequently the diversity of the mathematical ideas they bring, contribute to the enrichment of the classroom experience of mathematics learning. As Wilson (1992) says: "New entrants bring questions, fresh ideas, new and different perspectives on old problems, new energies, and new skills. [...] The experience they bring enlarges the repertoire of strategies that can be employed" (p. 4). It seems, therefore, that diversity in the mathematics classroom can be considered as both an obstacle to learning and a resource for learning or, as Alrø, Skovsmose, and Valero (2005) call them, the sameness discourse and the diversity discourse. The first approach considers sameness as a prerequisite for learning and thus diversity must be 'invisible' in the pupils' interaction since sameness is about asking the others to 'become like us'. On the other hand, the diversity discourse emerges while pupils interact and communicate. Pupils experience diversity as they try to convince others and wish to get to know more about their perspectives. In essence, it can be seen as openness to different perspectives, mutual respect for the different, and a willingness to understand and learn from what is different (Alrø \& Skovsmose, 2002). In their study of pupils in sixthto-eighth-grade multicultural mathematics classrooms Riskowski and Olbright (2010) found that diversity facilitated appreciation of working with others from a different background, as well as the development of metacognition.

\section{Conflict}

Vithal and Valero (2003) highlight the role of conflict as a key pedagogical concept in mathematics education, claiming that mathematics education as a field of practice and research has to be concerned with the implications of recognizing any kind of social conflict situation. Conflict seems to be the result of diversity and can be understood either as a potential for learning by opening up new possibilities or - in negative terms - as something that could cause an obstacle to learning and therefore should be avoided (Alrø, Skovsmose, \& Valero, 2003; 2005). This dual character of conflict is documented in several studies that examine the progressive shift from monocultural to multicultural classrooms (see for example the work of Adler, 2001, and Vithal, 2003). In this paper, this duality is seen through the lenses of the sameness and diversity discourse. In 
the sameness discourse conflict is problematic and it mainly concerns the 'different', which has to be 'normalized' in order to be integrated. In the diversity discourse, the virtue of 'different' is very much appreciated. In this study, the multicultural classroom is seen as a space for communication in which conflicts can be either part of interpersonal relationships among pupils or related to competencies in mathematics. At this point, it has to be acknowledged that multiculturalism is just one of the sources that might lead to conflict in the classroom.

The positive aspect of the notion of conflict might be connected with what Roos (2019) calls the 'discourse of participation'. She emphasizes the need for an inclusive spirit in the mathematics classroom, where all pupils have opportunities to participate in mathematics activities, thus seeing inclusion as a social process of participation in the mathematical practice. Schmidt (2016), working with Grade 1-3 primary school pupils, illustrates vividly how pupils do their best to participate in the learning community of their classmates and especially how pupils who might cause conflicts often try to work on the part of the task they can manage without causing trouble or disturbance for anyone else. The negative aspect of conflict is connected with the fact that classmates play a fundamental role in shaping learners' practices. As Bishop (2001) writes, classmates are the 'significant others' who will be particularly influential for the new (foreign) pupils. More precisely, he examines some migrant arrivals into a new class in Australia and shows how the pupils themselves categorize and classify their classmates according to stereotypes and act accordingly in ways that reinforce them.

\section{Methodology OF THE STUDY}

This is a small-scale instrumental case study (Denzin \& Lincoln, 1998) in the sense that 'a particular case is examined to provide insight into an issue' (p. 88). The aim is to examine the issue of change in primary education and specifically the issue of 'difference' in mathematics classrooms. Therefore, the choice of this case was made because it is expected to facilitate and advance our understanding of that bigger issue.

\section{Participants}

Twenty-three Grade 4 pupils (nine to ten years old) from a state school in an urban area of Prague, Czech Republic, participated in this study. The participants were asked to work in five groups formed on the basis of similar skills in mathematics according to their teacher. This specific class had had experience in working in groups since Grade 1. Interestingly, this classroom had been following Hejnýs method (2012) in mathematics from the first grade. This is a constructivist method emphasizing building mental schemes of mathematical concepts using conflict and critical discussion to reveal the mathematical 
truth and develop pupils' autonomy in mathematics. Hejnýs method is a recognized educational method and is applied in more than $20 \%$ of Czech schools. The method is aligned with the National Curriculum RVP ZV (Framework Educational Program for Basic Education) and in this specific class the pupils' mathematical knowledge was on the expected level according to this framework. Therefore, they were familiar, among others, with numbers and operations, 2D and 3D geometry, and problem-solving of non-standard problems (RVP ZV, 2017). The pupils had some experience with pattern tasks (numerical or geometrical) that are appropriate for approaching mathematical generalization, but they did not have any experience with using letters as variables to express relationships. For the purposes of this paper, we follow two groups, A and B, of five and four pupils respectively.

Group A included three local pupils (let us name them Kryštof, Cyril, and Anička) and two foreign pupils (let us name them Thomas and Zakhar) from the USA and Kazakhstan respectively. Thomas has some Czech roots and joined this class from Grade 1 . He is able to communicate fluently in Czech and is considered a rather advanced pupil. Zakhar joined this class two years ago. The teacher devoted much time and energy to supporting him in developing his Czech language skills to be able to communicate his work and ideas with the class. At the time this study took place his language skills had improved considerably but he still needed to try hard to be continuously in touch with the content of a discussion. Sometimes this is exhausting for him and he needs some time to recharge in order to continue.

Group B included three local pupils (let us name them Marina, Luky, and Eli) and one pupil (let us name him Alexander) from Russia. Alexander also joined this class in the middle of Grade 1. His Czech language skills have improved but he is still frequently lost when it comes to word games, colloquial expressions, and difficult constructions. He is prevented by his family from participating in outdoor class activities. This seems to have an impact on his communication with his classmates.

\section{The task}

The task given to the pupils was a generalization task and was divided into two parts (worksheets A and B). The same task can also be found in other studies (see, for example, Blanton and Kaput, 2005; López Centella, 2019). During the first part, the pupils had to find out the rule that leads to a general principle in order to predict the number of guests that can sit at any number of grouped connected trapezoid tables (Fig. 1). Then, during the second part, they had to work in the reverse direction and use the rule they had already found in order to find the number of the guests given that they know the number of connected tables (Fig. 2). 
In a celebrations room, all the tables have this shape: $\square$ and the guests are sitting in this way:

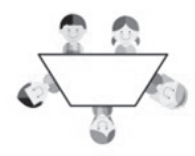

If there are more guests, the tables are joined as follows:

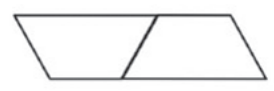

(1) How many guests could sit at 2 tables joined in that way?

(2) What about 3 tables?

(3) How many guests could sit at 9 tables joined in that way? How do you know it?

(4) How many guests could sit at 50 tables joined in that way? How do you know it?

(5) Explain how you find out the number of guests if you know the number of tables.

Figure 1 Worksheet A - Find out the number of guests

(6) If there are 26 guests sitting, how many tables are there?

Answer and explain:

(7) If there are 62 guests sitting, how many tables are there?

Answer and explain:

(8) Explain how you find out the number of tables if you know the number of the sitting guests. Answer and explain:

Figure 2 Worksheet B - Find out the number of tables

The task was considered suitable for the purposes of this study since it allows communication between the members of the group and it is amenable to multiple solution strategies (counting, drawing, modelling, asking for numerical relation- ships) which combine a variety of representations (pictorial, manipulatives, numerical, verbal, tabular), including at the same time different functional relationships (recurrence, covariation, and correspondence). This richness of the task was 
expected to facilitate our identification of whether the presence of foreigners in each group had an impact on the problemsolving process, i.e. whether this was an obstacle or an opportunity to strengthen collaboration.

At the same time, and in order for the task to be aligned with the pupils' experience, the task was designed collaboratively by all four authors in accordance with Hejnýs Theory of Generic Models (2012). The theory describes the mechanism of gaining knowledge in mathematics. It consists of five stages. The process starts with (internal) motivation - tension between 'I don't know' and 'I want to know', or 'I cannot do that' and 'I want to be able to do that'. Within the first stage of 'isolated models' pupils gain experience of several concrete cases (isolated models of a future piece of knowledge) which have something in common. Therefore, the first figure presenting one table with five guests and items 1, 2, and 3 (two, three, and nine tables respectively) can be considered isolated (concrete) models. When pupils discover the underlying common core idea and use one model to represent isolated ones (mental shift of generalization - second stage), they construct a generic model (third stage) of a future piece of knowledge. Item 4 (50 tables) aims to generalize by asking the pupils to identify a rule for finding the number of guests given the number of tables, which corresponds to the generic model. If pupils really draw 50 tables and make dots or dashes for guests, their knowledge of the relationship between the number of tables and the number of guests is still on the level of isolated models.
The 'sameness' of the solved cases has not been yet noticed. However, if, for example, they draw only one edge-table and one (or ten) joined tables with dashes for guests and they explain that 'at the two edge-tables there are eight guests sitting and at each one of the other 48 tables there are three guests sitting, which is 152 guests altogether', the pupils' knowledge is on the level of a generic model and they would be able to count it for any number of tables. This approach could be used for any given number and this is why the case of the number 50 plays the role of a generic model. By the mental shift of abstraction (fourth stage), the abstract knowledge (fifth stage) is developed. In our case, when 'any number' is expressed by a letter or a symbol or a sign, that means, the language of numbers has changed into language of signs or symbols, which is a process of developing abstract knowledge. Item 5 constitutes a shift to abstract knowledge. The general rule for the first part is expressed through the function $g(n)=3 n+2$ (by $n$ denoting the number of tables and $g(n)$ the number of the guests for a given $n$ ). The second part aims at the reverse relationship $n(g)=\frac{g-2}{3}$. In this case, $g$ denotes the number of guests, whereas $n(g)$ is the number of tables for a given $g$ (for reasons of simplicity $g-2$ is always a multiple of 3 ). By this reverse process the knowledge that has been reached is conceptualized. However, even though some studies leave open the option for young pupils to accomplish the specific abstract stage (Blanton et al., 2011), it is not something expected of primary school pupils (and it is still difficult for secondary school ones). 


\section{Collection and analysis of data}

The pupils were asked to work at their own pace and solve as many items as they could. The duration of the session was about 45 minutes and the pupils were asked to solve the items linearly, starting from worksheet $A$ and explaining in writing their solution process and results for each of the questions on their worksheets. They were forbidden to erase any content of their work and this is why they were given more than one worksheet. It was a non-interventive session and therefore no feedback was provided during the session. The whole session was video-recorded. This class is used to having visitors and being video-recorded. Therefore, the presence of video cameras in the classroom was not expected to have a negative influence on the study. The pupils' verbal interactions were transcribed and translated from Czech to English for the purposes of the study. The transcribed protocols, together with the pupils' worksheets, as well as the notes compiled by the researchers while observing the working groups, constituted our data. The data analysis took place at a qualitative level on the basis of content analysis following a more deductive sort of thematic analysis (Mayring, 2014). A list of themes was developed in advance, coming from theory, from other studies, and from previous research (in our case the themes are 'diversity' and 'conflict'). Then the entire material was coded with those categories by assigning each category to a passage of text. As a coding guideline for this we followed two criteria: on the one hand, to identify instances of diversity that seem to promote mathematical meaning-making and on the other hand, to identify instances of conflict recording how this had an impact on the groups' construction of mathematical meaning. Finally, all the coded material per category was extracted and summarized.

The whole study was prepared by the four authors of this paper. However, one of the authors has been following the class's mathematics lessons since Grade 1 and was well-informed of the characteristics of this class. She has the experience of long-term observation of this class, having collaborated very often with their teacher on several projects. Therefore, statements made about certain pupils in the class are based on her longitudinal observation and her discussions with the teacher. This is why she was the one who presented the tasks to the pupils and explained the process that should be followed. One more member of the research team was physically present in the classroom observing the groups. These two performed the initial analysis of the collected data and then this analysis was checked by all four of us. The results of the analysis were compared and clarified and some of them were rediscussed until agreement between all four of us was reached.

\section{Results}

The two groups behaved differently during their problem-solving effort. Group A demonstrated an implicit under- 
standing of the significance of diversity which provided them with opportunities for learning, while group B chose explicitly to exclude one of its members, thus allowing the emergence of a conflict that had an impact on the way the mathematical ideas of the problem were negotiated. Both cases are described below.

\section{Group A - Towards a common understanding}

Worksheet A comprised of five items. For the first item (asking the number of guests for two tables) Cyril and Thomas counted - virtually without any drawing - the potential guests one by one and Anička wrote down the answer: eight guests. The next item asked for the number of guests for three tables. Thomas suggested that considering four guests per table was not a valid option since the tables were joined and consequently, they could not have guests at the two edges of each of them. However, it was not easy for Zakhar to visualize the process:

\section{Zak.A.1 It will be better to draw it.}

Immediately, Anička drew the third table properly and counted the guests loudly one by one and wrote down the answer: 11 guests.

They then had to find out the number of guests for nine tables (Item 3). Even though it would be expected to consider it as a chance to use (mistakenly) proportional thinking (nine tables is a multiple of three tables), the pupils preferred to draw the nine tables instead (Fig. 3). So, Thomas took the pencil and drew the tables. Then Anička drew dots representing

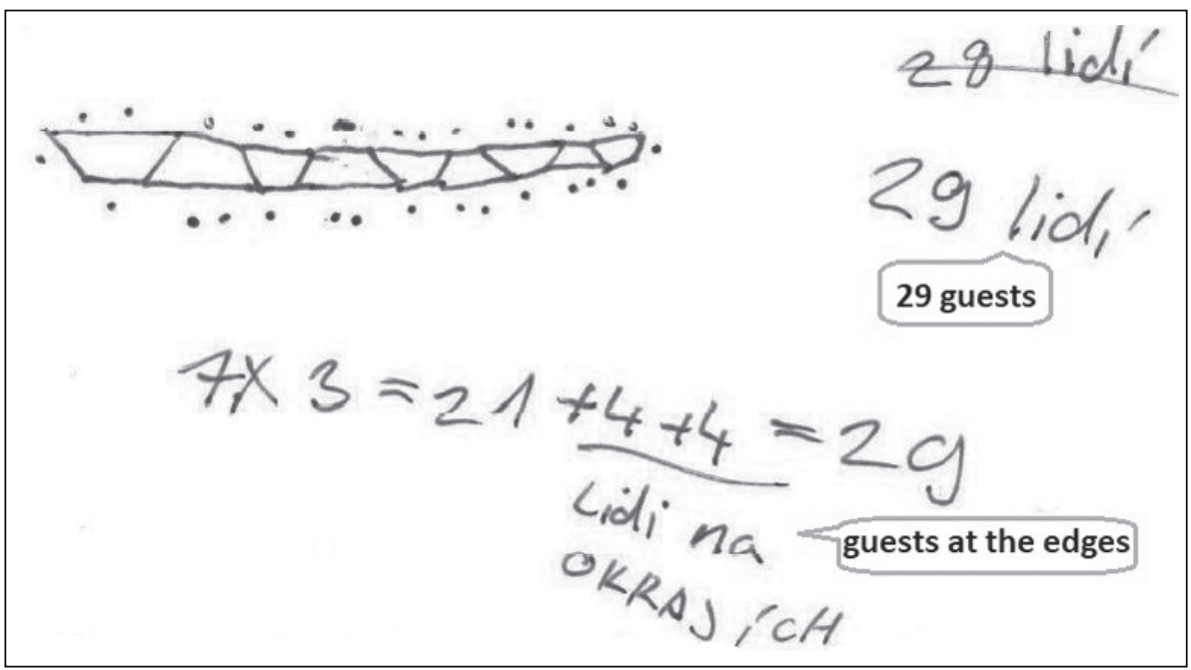

Figure 3 Group A working on the number of guests for nine tables 
the guests, they counted the dots, and all agreed that there were 28 dots (instead of the correct number, 29). At this point, it went unnoticed that while drawing they had missed one dot at one of the tables.

The next item was a surprise for them.

Cyr.A.2 My God! 50 tables!!

Kry.A.3 We have to multiply somehow!

At this point, the first evidence of a potential strategy appears. To draw 50 tables is a huge amount of work and it is not an option for the group. Cyril suggested forming groups of tables, making it easier to get the number of guests for each group. So, they split the total number of tables into five tens. Kryštof said loudly: $3 \times 10=30,30 \times 5=150$. Anička wrote 150 immediately and all of them agreed. This calculation left the two guests at the two edges in the row of tables unnoticed. Indeed, each group of ten tables does sit 30 guests and since there are five groups of ten the number of guests will be 150 . But then you have to add the two guests who are sitting at the edges. At the moment the pupils missed that 'detail' and they felt ready to move on to the next item.

However, Anička went back to this for a while:

Ani.A.4 We have not added these...

She noticed that they had forgotten to include in their calculation the extra guests who are sitting at the edges of the series of tables. So she suggested adding eight more guests, to which everyone agreed (Fig. 4).

This strategy is valid if one initially considers $n-2$ tables with three guests and then two more tables (the first and last) with four guests. They totally missed the fact that six of these guests had already been included in the initial calculation and that they had just to add two more to complete the answer.

At this point, Zakhar (who was still struggling with his fluency in the Czech language), expressed the need for an explanation. Suddenly, all of them stopped and Thomas took the initiative to explain

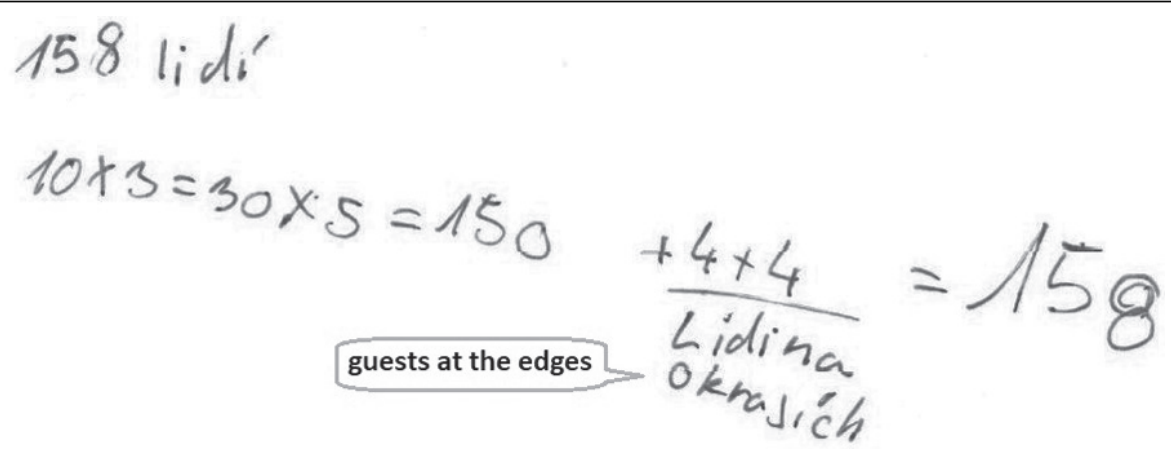

Figure 4 Group A calculating the guests for 50 tables 
to Zakhar. He decided to use the previous item, which was simpler, in order to clarify what they were doing to the current one.

Tho.A.5 We can do this in entirely the same way. We have... one, two, ..., seven tables and $7 \times 3=21$.

Cyr.A.6 Plus those at the edges.

Tho.A.7 Now it is a little bit confusing.

The shift to the previous example, and the effort to use it to explain to Zakhar, made Thomas realize that something had gone wrong with their answer (28 guests for item 3).

Tho.A.8 Either the calculation is wrong, or the strategy does not work in this case.

Careful implementation of the strategy $[(n-2) \times 3+4+4]$ resulted in the correct answer of 29 guests instead of the 28 they had initially answered. They were able to explain that the mistake was due to a missing dot at one of the tables and to the fact that they were relying on counting as their strategy to find the answer. In Figure 3 above it can be seen that the pupils corrected their answer by crossing out 28 and writing 29 instead, adding the missing dot at the same time. However, they did not check whether they had applied the strategy correctly to the case of 50 tables and thus they moved on to the final item on this worksheet. They were now ready to consider the general case (Fig. 5).

Although they were not entirely correct, these young pupils were able to use a question mark as a representation of

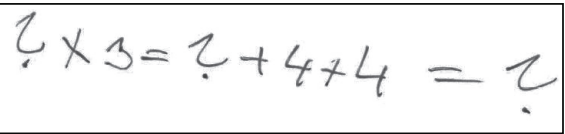

Figure 5 Group A: The general case for $n$ tables

a variable to express a general rule. They verbalized the question mark as "something" which allowed them to interpret this differently each time according to the situation. It is easy to recognize their correct understanding of the rule in this mistaken expression. The first question mark refers to the number of tables after the exclusion of the two tables at the edges. Therefore, the first multiplication results in the number of guests for $n-2$ tables. The second question mark is the result of this multiplication and then it is necessary to add twice the number four to include the guests for the two tables at the edges. The final question mark stands for the total number of guests.

Worksheet B (items 6, 7, and 8) invited the pupils to work in a reverse way, to find the number of tables given the number of guests.

For item 6 (how many tables for 26 guests) an unusual approach was followed. They put both worksheets one next to the other and Thomas was the first who noticed that they could use item 3 from worksheet A (nine tables) to find the answer for item 6 .

Tho.B.9 Wait!! 26 guests are $29 \mathrm{mi}-$ nus three (he points to item 3, worksheet A).

Kry.B.10 What do you mean 'minus three'? 
Tho.B.11 Here! (He points to the seventh table, Fig. 3.) Here! Three guests are sitting here. When you take this table away you have 26 guests. Or here! (He points to another table.)

This was an effective and smart metacognitive action in the sense of Flavell's (1979) 'thinking about thinking' that allows the solver to select appropriate strategies to adjust their behaviour to changing task demands and make use of the awareness of previously gained knowledge (Montague, 1992). Indeed, each one of the intermediate tables does allow three guests to sit. Thus, if any one of the intermediate tables is excluded the number of the guests is reduced to 26. However, 29 was the number of guests (item 3) who could sit at nine tables. Therefore, if one table is excluded (which means that consequently the number of guests is reduced to 26) the final number of tables becomes eight.
Ani.B.12 Oh! So, the answer is eight tables. Here (Fig. 3) there were nine tables. Therefore, the answer now is eight tables.

Kry.B.13 This is so clever!

Tho, Cyr.B.14 Eight tables!!

Although this was a correct answer it cannot guarantee the general rule. Interestingly, in the next item (62 guests) they did not follow the same strategy. The first guess was the case of 20 tables and therefore, in this case, the first step of their rule $(3 \times n)$ gives a total of $3 \times 20=60$ guests. Then according to their rule, they claimed that the total number of guests should be 64 guests. Anička asked her classmates to focus on the fact that there are eight guests at the edges who can be temporarily ignored. Therefore, the total number cannot be 62. Instead, she wrote $62-4-4=54$ (Fig. 6).

Cyril connected both fours, writing an eight above them (Fig. 6), and his question was:

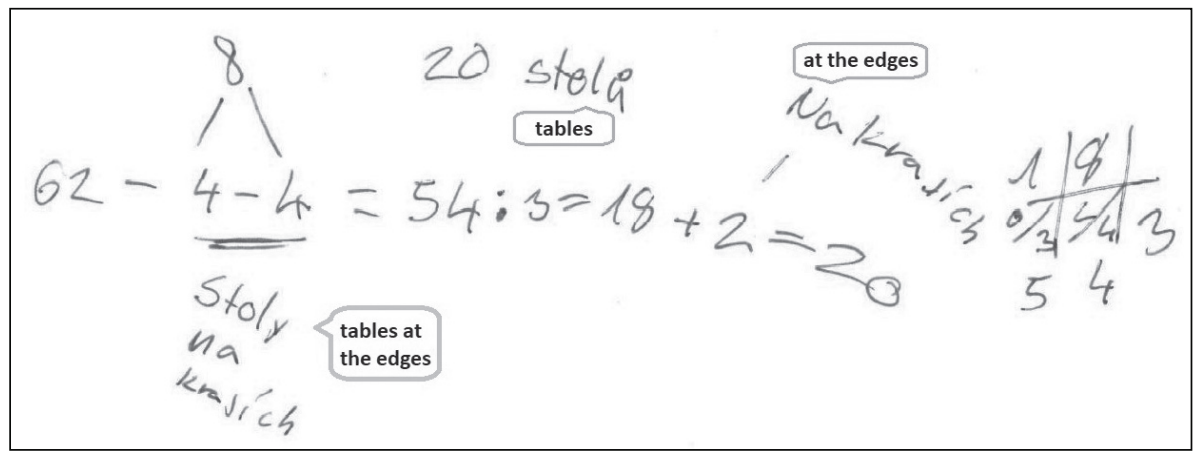

Figure 6 Group A: From 62 guests to 20 tables 
Cyr.B.15 So, three times what makes 54 ?

Ani.B.16 $18 ! 54 \div 3=18$ !

Kry.B.17 So, we need 18 tables.

Kry.B.18 No! Wait!

He pointed the two fours and suggested adding two to 18 to get the correct result of 20 tables.

The general rule now became evident. First subtract twice the number four, i.e. the guests at the two tables at the edges. Then divide the result by three to find the number of tables between the edges. Do not forget to add two to this quotient.

Thus, they were now ready to move on to the final item to present this final rule more abstractly.

Cyril suggested and Anička initially wrote the first part of the expression showing that from a given number of guests (first question mark) we subtract twice the number four. The next question mark denotes the guests sitting at the tables that exist between the edges and therefore to find the number of these tables this ques- tion mark should be divided by three. The third question mark is the quotient of this division. This number increased by two gives the total number of tables (Fig. 7).

Despite the expression not being mathematically correct, it gives a sense of the correct rule formed by all the members of the group (since in this group each claim and action was necessarily approved by all its members), which is in itself important considering how young these pupils are. This finding led them to revise all the previous ones and now they discussed item 6 in the light of the new rule and checked the accuracy of their answer.

\section{Group B - Separate paths}

It seems that in group B Marina was the leader. She is a very ambitious pupil and prefers to collaborate only with classmates who can help her to accomplish tasks successfully. From the very first moment, the three local children under her leadership excluded Alexander, the child

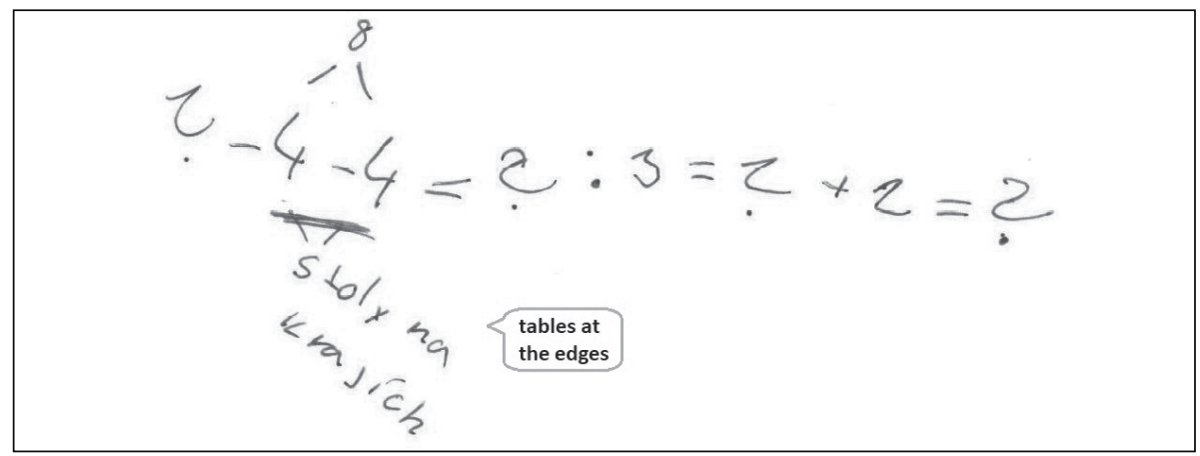

Figure 7 Group A: The general case for $n$ guests 
from Russia, from their group by saying to him "You are so dull." This was due to his lack of language skills, which prevented him from adequately understanding what was said or written. This meant that there were two parallel efforts. One copy of worksheet A was completed by the three children and another one individually by Alexander, who was sitting next to them. As will be seen below, Alexander tried hard to get accepted by his local classmates by offering suggestions or providing explanations from time to time.

For item 1, objecting to the suggestions made by Eli, who suggested that the number of guests should be ten, Marina pointed out the place of each guest, counting one by one until the correct number, eight. At the same time, Alexander also found the correct number very easily and immediately moved on to the next item and drew the third table (Fig. 8). He used dashes as a representational tool to denote each guest (a tool that was also adopted by the other three pupils, without any credit to Alexander). How- ever, he made a mistake while counting which resulted in the wrong number of ten guests.

He tried to contact his group.

Ale.A.1 Have you got the result? I found eight guests for the first item and ten for the second.

Luk.A.2 For three tables there cannot be ten guests.

Ale.A.3 Why?

Luk.A.4 When you add one table...

Luky counted the dashes in their worksheet and found there were 11. This led Alexander to come back to his worksheet. He counted the dashes again.

Ale.A.5 You are right. It is 11.

And he corrected the number on his worksheet (Fig. 8).

Then both parts of the group started dealing with item 3 . They drew nine tables and represented the guests with dashes (the group of three children) or with dashes and numbers (Alexander) (see Fig. 9).

Alexander tried to communicate with the other three children by letting them

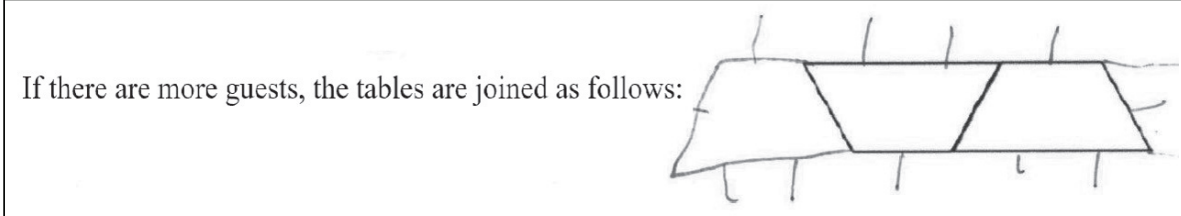

(1) How many guests could sit at 2 tables joined in that way?

(2) What about 3 tables?

Figure 8 Alexander corrects his result for item 2 


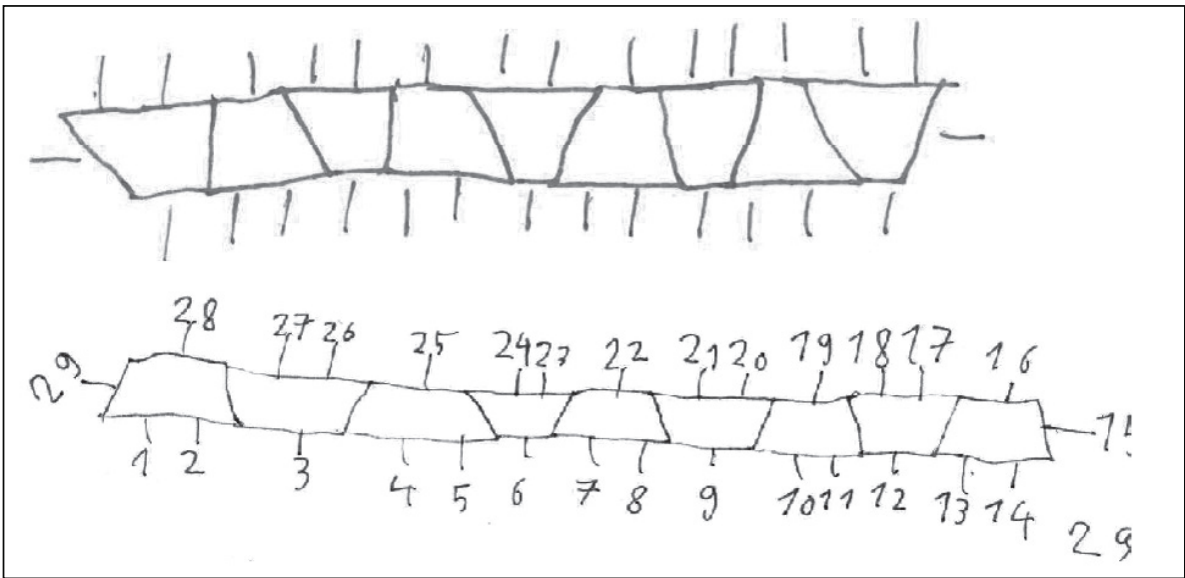

Figure 9 Drawing the case of nine tables (above by subgroup and below by Alexander)

know his result, but Marina reacted angrily to his effort. Both subgroups wrote the correct answer of 29 guests on the basis of counting them one by one.

Then, Alexander again took the initiative to make contact.

Ale.A.6 I have an idea.

In order to find the number of guests for 50 tables (item 4), he thought of using a simpler problem. He drew a collection of ten tables as a first step and used dashes to denote the guests.

Marina laughed at him for a linguistic mistake he made but she adopted without any comment his idea. However, they continued working separately.

The subgroup of three children drew the first ten tables. They initially used dashes for both ends of the ten but after Eli's suggestion, they erased the dash at the right-hand end (Fig. 10). Alexander drew the last ten and this explains the fact that the $16^{\text {th }}$ guest is denoted at the righthand part of the tables while at the same time there is no guest at the left-hand edge of the row (Fig. 11).

The task refers to five groups of ten tables. The subgroup misinterpreted the situation.

Luk.A.7 We have 31 guests...

$$
31+31+31
$$

Luky referred to the three groups of ten tables that exist between the first and the last ones. He missed the fact these three groups of ten tables have only 30 guests each (Fig. 12) since they do not allow guests at their edges. On the other hand, Alexander exhibited a deep understanding of the situation. As can be seen in Figure 11, he calculated the number of guests by adding three numbers: $31+90+$ $+31=152$. The first number represents the guests who sit at the first ten tables. The next three groups of ten sit 90 guests since no-one can sit at the edges of the tables. 
Papadopoulos, I., Jirotková, D., Slezáková, J., López Centella, E.

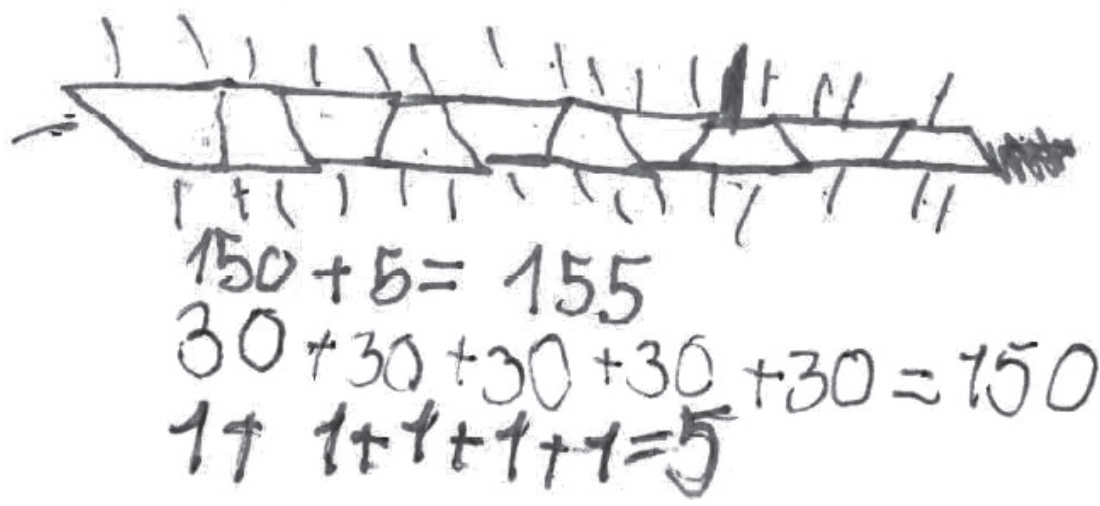

Figure 10 Solution for item 4 provided by the subgroup of three children

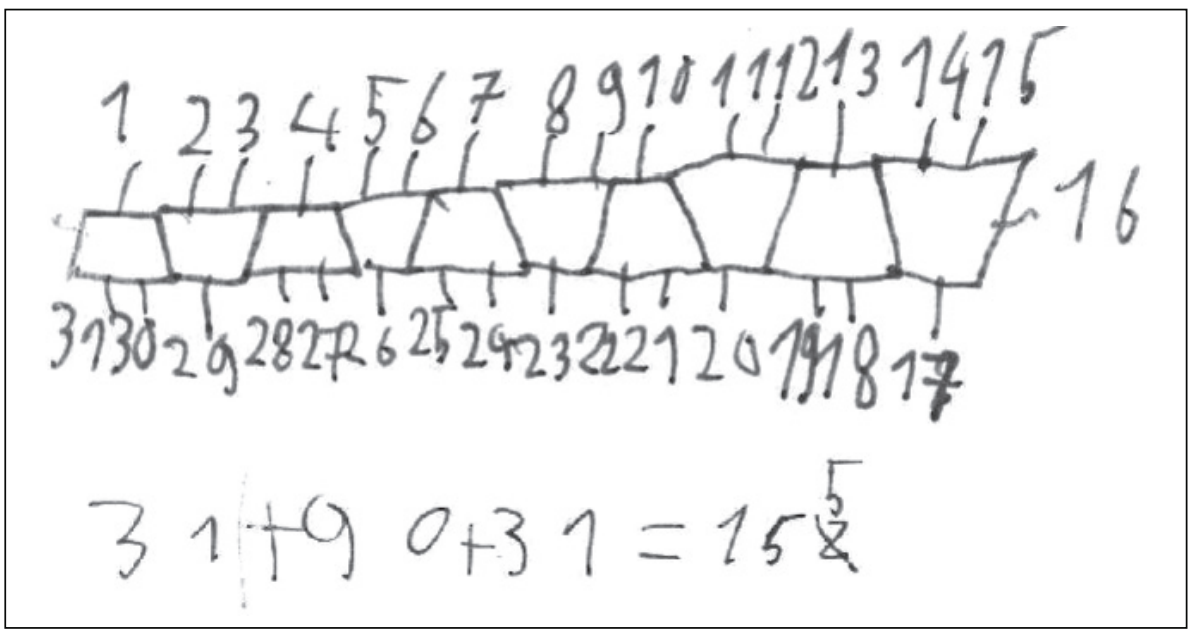

Figure 11 Solution for item 4 provided by Alexander

Then again 31 guests are added because of the last ten tables.

It is interesting to follow the interacton that took place between Alexander and his classmates.
Ale.A.8 152 guests.

Luk.A.9 155 guests.

Ale.A.9 152. According to my calculations, the answer is 152 .

498 


\section{Luk.A.10 Really? Is it 152 and not 155 ?}

Marina took Alexander's worksheet and looked at it. She commented negatively on the three numbers $(31,90,31)$ he wrote. This led him to cross out number 2 in his correct answer and write 155 instead of 152 (Fig. 11).

The next item asks the general rule for finding the number of guests if the number of tables is given. To understand exactly what is asked for in this item one has to possess adequate fluency in the Czech language since the statement of the task does not include any numbers and the solver has to read the text carefully. One of the researchers soon realized the difficulty Alexander was having coping with this item, mainly because he was not a native speaker. Therefore, she tried to explain it, addressing, however, the explanation to the whole team rather than only to Alexander. To encourage him she asked him to explain again to the whole team his way of thinking for the last item he solved correctly (i.e. item 4 ).

Ale.A.11 So, ...there should be $3 \times 30$, that is $90(\mathrm{He}$ pointed to the three tens in the middle). And then on both sides ... there are $31+90+31$.

Luk.A.12 $5 \times 30=150$, and $1+1+1+1+1$ equals five.

Ale.A.13 No one is interested in my opinion.

His last comment was addressed to the researcher, who again encouraged a discussion among the members of the group.
Luk.A.14 31 guests are sitting at each ten tables.

Ale.A.15 No, not at each ten tables.

Luk.A.16 For each ten tables there are 31 guests.

Ale.A.17 No! This holds only for the first and last groups of ten tables.

Luk.A.18 No, no!

Ale.A.19 Wait... My opinion is...

Luk.A.20 We know we have the correct result.

At this point, the bell rang and the pupils handed in their worksheets without being able either to find the general rule or to move on to the second worksheet.

However, Alexander, before leaving the classroom, angrily and ironically pointed at the two tables at the edges and said:

Ale.A.21 Someone will sit here. Therefore, 31 is valid only for the first and last ten tables. So, the number of guests will be $2 \times 31$ plus $3 \times 30$.

His comment made Marina and Luky turn against him one more time. They addressed him in a way that could be considered offensive since they used their fingers to explain why the result should be 155 , as if it were being addressed to a much younger pupil.

Mar.A.22 Alexander, see here. How many are they? $1+1+1+$ $+1+1$ (showing her fingers).

Lukas showed at Marina's fingers and repeated:
Luk.A.23
$1+1+1+1+1$ and $30+30+$ $+30+30+30$. So, 155 . 
All this time Eli was observing without participating in the discussion. The whole discussion ended with Alexander saying once again that there would only be 31 guests at the first and last groups of ten tables. After that, they left the classroom.

\section{Discussion}

The first thing to be mentioned in this section is that through our visit to the classroom we did not see instances of diversity being present in an explicit way. It was mainly after analyzing the data that diversity became noticeable and this made us think that instances of diversity remain rather hidden. Moreover, it is necessary to remind that we were interested only in two concepts relevant to the landscape of learning: diversity and conflict. Conflict in our case is caused by the diversity (of any nature) of the pupils in the group. We focus on conflicts that influence the problem-solving process. More specifically, we try both to observe the influence and to reveal the reasons for the conflicts. It seems that there are two key behaviours for this: the presence or lack of openness in groups. Diversity and conflict represent our way of looking at the landscape and this justifies in an indirect way the methodological decisions we made, which is connected with our observations that were made possible in situ.

\section{How might this classroom diversity enhance collaborative mathematical problem-solving?}

The first research question considers how diversity enhances collaborative problem-solving in the classroom. This enhancement affects both the pupils' behaviour while working in groups in terms of metacognition and their mathematical knowledge.

Group A is a typical example of the power of diversity being exhibited in their collaboration. Each suggestion made by the participants was respected, discussed, and evaluated. From the very first moment Zakhar (the pupil from Kazakhstan who was struggling with his fluency in the Czech language), who found it difficult to visualize the whole process, suggested using drawings as a way to facilitate visualization (Zak.A.1). This was taken seriously by the rest of the members of the team. Even though it was easy for some of them to work mentally, especially for the first items, they decided to use drawings in order thus to share a common understanding of the situation. This helped Zakhar to follow the problem-solving process and allowed him to enrich his mathematical experience. In the same spirit, when Zakhar later expressed the difficulty he had in understanding how his classmates managed to use a rule to get the number of guests for 50 tables, all the other members of the group paused the solving process temporarily and Thomas (Tho.A.5), the other foreign pupil (from the USA), took the initiative to explain to him using the items on the worksheet that had already been solved. They then went one step further and showed that the collaboration was facilitated and promoted through 
their willingness to consider any ideas and suggestions made by the other pupils. In his effort to explain to Zakhar Thomas realized that something was wrong with one of their previous answers (Tho.A.8). His classmates took it seriously and this helped them to find, explain, and correct the mistake made earlier. Indeed, comparing the general relationship with partial results can lead to a confirmation of the rule or to the identification of possible mistakes. This collective action of looking back at the problem-solving process is an instance of the contribution made by diversity to the pupils' metacognitive skills.

Finally, this collaboration was promoted further when the participants acknowledged the contribution of each member to the collective work. When Kryštof realized the efficiency of the reverse rule given by Thomas while explaining how to get the number of tables if the number of guests is known he spontaneously said: "This is so clever!" This is an instance of the constructive atmosphere that was built in group A which exploits the existing diversity of the participating pupils in a positive way. It seems, therefore, that diversity enhanced the pupils' skills at listening to, valuing, analyzing, evaluating, and incorporating a broad range of views (Herzig, 2005) by formulating ideas and communicating them with others, offering explanations, monitoring, and revising their thinking, and recognizing mistakes and contradictions (Ing et al., 2015; Hatano, 1993).

It seems, however, that diversity also has a positive effect on the pupils' learning in terms of mathematical content. Interestingly, in order to express their general rule in a formal way the pupils invented the use of a question mark to denote the unknown quantity (Fig. 5). So, although they were not aware of the use of letters as variables, they exhibited an intuitive knowledge of this. This is important in itself, given that these pupils had no prior experience with the notion of variables. Of course, this expression of the general rule is not entirely correct since in each one of its parts the question mark represents something different, which leads to a misuse of the equals sign. But, no matter whether correct or not, their initiative to use a symbol to denote the unknown is a step closer to the use of symbolic language that will be formally introduced to them later. Ayala-Altamirano and Molina (2020) also observed similar instances in their study when pupils used the same symbol to represent more than one variable.

\section{How might the potential conflict in collaborative problem-solving influence the problem-solving process?}

In contrast to this group, the work done by group B highlights how the lack of diversity in the sense presented above, as well as the presence of conflict (in a negative sense), might be an obstacle to mathematical learning.

From the very first moment the labelling made for Alexander (the pupil from Russia) ("You are so dull") created a nega- 
tive climate. As Bishop and Kalogeropoulos (2015) say, "labeling is a classic way of excluding learners...In this situation, the learner comes under the powerful influence of "significant others"' (p. 200). Thus, Alexander was excluded from the group (actually, his exclusion was imposed by Marina, one of the members) and he worked individually in parallel with the rest of the team. In situations like this, the results will be a problem if the pupil concerned is less confident than Alexander. But as we will show below, he made an effort to stand up for himself. It is to be hoped that this experience will not have a long-term negative impact on him.

Alexander tried to confront this conflict by offering from time to time suggestions that would facilitate the solution of the problem (Ale.A.1 - Ale.A.9). This aimed to convince his classmates to accept him as part of the group. This is in accordance with Schmidt (2016), who describes how hard excluded pupils try to participate in the learning community. Alexander did his best to avoid causing conflict in the group. This was identified in several cases. Initially, he suggested using dashes as representations of the guests but was ignored. Later, and despite the fact that he had suggested the correct number of guests for item 4 (152 guests), the fact that Marina commented negatively on his way of writing the three numbers involved in his computation $(31,90,31)$ caused him to abandon his correct result and accept the mistaken one just to be part of the community (Schmidt, 2016). Although his suggestion was correct, no one from his group was willing to listen to him and consider his suggestion. There was no discussion; only Marina assertively explained to him that their counting was correct. The counting itself was correct but it did not express the correct relationship. The fact is that Alexander's way of thinking was extraordinarily interesting from the mathematical point of view. He made three sub-groups of tables, two groups of ten tables at the edges and one group of thirty tables between the edges. This was a strong approach that would support the finding of the general rule. However, the group missed that opportunity because of the tendency to ignore any suggestion being made by Alexander. Although he gave arithmetical evidence of his calculations (Ale.A.8 - Ale.A.19), Luky refused to think about them and closed the discussion by announcing "We know we have the correct result" (Luk.A.20). Actually, Alexander simply confirmed what he already knew, as can be seen in his comment (Ale.A.13): "No one is interested in my opinion." In this case, on the one hand, this Alexander's behaviour shows his desire to be part of their community, which, however - as a result of his decision to deliberately accept wrong answers as correct - might result in his losing selfconfidence in the long term. On the other hand, a strong mathematical idea went completely unnoticed, which is a great loss for the pupils' mathematical learning.

Whenever one of his ideas managed to cross the boundaries and be used by his three classmates, no one gave credit to him for his contribution. For example, 
in his first steps while solving the task he made a mistake (Ale.A.1) and made the necessary correction according to the results gained by his classmates in the subgroup (Ale.A.5). This led him to develop a tool to solve the tasks in a more semantic way, thus avoiding similar mistakes in counting. Therefore, he started using dashes as an effective strategy to visualize the guests. This was a representation used later by the subgroup of three pupils, but no one thanked Alexander for his idea that helped them to move forward. The same happened with Alexander's strategy of using groups of ten tables. He proposed his idea (Ale.A.6) and Marina laughed at him for a linguistic mistake he made, but she adopted his idea without any kind of acknowledgment of his contribution.

This group did not manage to complete worksheet A and find the general rule and consequently, they did not have time to move on to worksheet B. Alexander's comment A.21 expresses his emotional situation. While leaving his desk he repeated angrily and ironically his main argument that would give the solution and that was outrageously ignored. This episode confirms that the pupils' participation is not only a matter of mathematical competence. A group of pupils is a social context and participation is based on how the participants and the knowledge they exhibit are valued by others. This was the main difference between groups $A$ and B. In group B there was no room for negotiation, and this is why the difficulties may have increased. Thus, this conflict in group B not only had a nega- tive influence on the making of mathematical meaning for the participating pupils but also caused strong emotional and affective responses (Gorgorió \& Planas, 2005).

\section{Conclusions}

In this paper, we aimed to highlight the need for 'openness' in primary school mathematics classes as a response to the context of the transformation of our societies from monocultural to multicultural ones. The change in the composition of the classroom population means not only new language in the classroom but also new thinking on the same issues, new strategies on the same problems, and different skills. We need to develop an attitude of openness; otherwise, some possible inspirational thoughts in mathematics might go unnoticed.

Examining the data from two groups from a primary class, we gathered some evidence about the impact of two phenomena that might appear in the mathematics classroom: diversity and conflict. We found that diversity facilitated meaning-making in mathematics via sharing ideas, discussion, and respect for the need for explanations. The pupils who worked in this positive context proved themselves able not only to find the generalization rule, but, moreover, to identify mistakes, modify solutions, and move from concrete representations to more abstract ones. The 'different' was not a barrier but a source of mathematical ideas that contributed to the solution. 
On the other hand, conflict that was caused by the lack of openness resulted in the exclusion of one of the participants and consequently in good opportunities for 'doing mathematics' being missed, as well as having a strong impact on the emotional and affective status of the excluded pupil. The pupil who was excluded from the group came back with a very strong strategy that seemed promising for reaching the rule for the general case. However, the rest of the group was determined to ignore his suggestions, and consequently, this group did not manage to solve the task, and obviously, they did not have time to move on to the second worksheet.

Our thesis is that there is a need for a proper response to the challenge posed for the educational system (no matter the geographical boundaries) to cultivate an atmosphere in primary classrooms that would see the 'different' as enrichment. More specifically for the case of the teaching and learning of mathematics, 'difference' must be seen as an opportunity that promotes the communication of mathematical ideas. Obviously, our results do not allow our findings to be generalized since we dealt with pupils in just one multicultural mathematics class. However, the findings are promising for planning a future study on the impact of diversity and conflict on pupils' mathematical learning in a multicultural class.

\section{ACKNOWLEDGMENT}

Esperanza López Centella gratefully acknowledges the academic and financial support she received from her research group FQM193 and the Plan Propio de Investigación of the University of Granada.

\section{REFERENCES}

Adler, J. (2001). Teaching mathematics in multilingual classrooms. Dordrecht: Kluwer.

Alrø, H., \& Skovsmose, O. (2002). Dialogue and learning in mathematics education: intention, reflection, critique. Dordrecht: Kluwer.

Alrø, H., Skovsmose, O., \& Valero, P. (2003). Communication, conflict and mathematics education in the multicultural classroom. In M. A. Mariotti (Ed.), Proceedings of the Third Conference of the European Society for Research in Mathematics Education. Bellaria: Pisa University. Retrieved from https://www.mathematik.uni-dortmund.de

Alrø, H., Skovsmose, O., \& Valero, P. (2005). Culture, diversity and conflict in landscapes of mathematics learning. In M. Bosch (Ed.), Proceedings of CERME4 (pp. 1141-1151). Sant Feliu de Guixols: Universitat Ramon Llull.

Alrø, H., Skovsmose, O., \& Valero, P. (2009). Researching multicultural mathematics classroom through the lens of landscapes of learning. Nordic Research in Mathematics Education, 13(2), 329-336.

Alrø, H., Skovsmose, O., Valero, P. (2010). A learning landscape: Building perspectives on mathematics learning in multicultural classrooms. In B. Sriraman et al. (Eds.), The sourcebook on Nordic research in mathematics education (pp. 651-669). Greenwich: IAP. 
Ayala-Altamirano, C., \& Molina, M. (2020). Meanings attributed to letters in functional contexts by primary school pupils. International Journal of Science and Mathematics Education, 18(7), 1271-1291.

Bishop, A. J. (2001). The transition experience of immigrant secondary school pupils: dilemmas and decisions. In G. de Abreu, A. J. Bishop, \& N. C. Presmeg (Eds.), Transitions between contexts of mathematical practices (pp. 53-79). Dordrecht: Kluwer.

Bishop, A., \& Kalogeropoulos, P. (2015). (Dis)engagement and exclusion in mathematics classrooms - values, labelling and stereotyping. In A. Bishop, H. Tan, \& T. Barkatsas (Eds.), Diversity in mathematics education. Towards inclusive practices (pp. 193-218). New York: Springer.

Blanton, M. L. \& Kaput, J. J. (2005). Characterizing a classroom practice that promotes algebraic reasoning. Journal for Research in Mathematics Education, 36(5), 412-446.

Blanton, M., Levi, L., Crites, T., \& Dougherty, B. J. (2011). Developing essential understandings of algebraic thinking for teaching mathematics in grades 3-5. In B. J. Dougherty \& R. M. Zbiek (Eds.), Essential understandings series. Reston, VA: National Council of Teachers of Mathematics.

Denzin, N. K., \& Lincoln, Y. S. (1998). Strategies of qualitative inquiry. Thousand Oaks, CA: Sage.

Ferguson, S. (2009). Same task, different paths: Catering for pupil diversity in the mathematics classroom. Australian Primary Mathematics Classroom, 14(2), 32-36.

Flavell, J. H. (1979). Metacognition and cognitive monitoring: A new area of cognitive-developmental inquiry. American Psychologist, 34, 906-911.

Gorgorió, N., \& Planas, N. (2005). Cultural distance and identities-in-construction within the multicultural mathematics classroom. ZDM Mathematics Education, 37(2), 64-71.

Gorgorió, N., Planas, N., \& Vilella, X. (2002). Immigrant children learning mathematics in mainstream schools. In G. de Abreu et al. (Eds.), Transitions between contexts of mathematical practices (pp. 23-52). Dordrecht: Kluwer.

Hatano, G. (1993). Time to merge Vygotskian and constructivist conceptions of knowledge acquisition. In E. A. Forman, N. Minick, \& C. A. Stone (Eds.), Contexts for learning: Sociocultural dynamics in children's development (pp. 153-166). New York: Oxford University Press.

Hejný, M. (2012). Exploring the cognitive dimension of teaching mathematics through scheme-oriented approach to education. Orbis Scholae, 6(2), 41-55.

Herzig, A. (2005). Goals for achieving diversity in mathematics classrooms. Mathematics Teacher, 99(4), 253-259.

Ing, M., Webb, N. M., Franke, M. L., Turrou, A. C., Wong, J., Shin, N., \& Fernandez, C. H. (2015). Pupil participation in elementary mathematics classrooms: the missing link between teacher practices and pupil achievement? Educational Studies in Mathematics, 90(3), 341-356. 
Kaiser, G. (2003). Learning mathematics within the context of linguistic and cultural diversity - an empirical study. In M. A. Mariotti (Ed.), Proceedings of CERME3, Bellaria. Retrieved from https://www.mathematik.uni-dortmund.de/

Kostelecká, Y., Hána, D., \& Hasman, J. (2017). Integrace žákư-cizinců v širšim kontextu [Integration of pupils-foreigners in a wider context]. Praha: Charles University, Faculty of Education.

López Centella, E. (2019). Functional thinking of third grade pupils: a study from early algebra framework. In J. Novotná \& H. Moraová (Eds.), Proceedings of SEMT19 (pp. 251-261). Praha: Charles University.

Mayring, P. (2014). Qualitative content analysis: Theoretical foundation, basic procedures and software solution. Klangenfurt: Beltz.

Møller, J. (2001). Identitet og kodevekslen hos unge tosprogede med dansk-tyrkisk baggrund [Identity and code exchange among bilingual young people with a Danish-Turkish background]. Kopenhagen: Danish School of Education.

Montague, M. (1992). The effects of cognitive and metacognitive strategy instruction on mathematical problem solving of middle school pupils with learning disabilities. Journal of Learning Disabilities, 25, 230-248.

Rámcový vzdělávací program pro základni vzdèláváni [Framework educational programme for basic education]. (2017). Praha: Ministry of Education, Youth, and Sports. Retrieved from www.nuv.cz/t/rvp-pro-zakladni-vzdelavani

Riskowski, J. L., \& Olbright, G. (2010). Pupil views of diversity through a multicultural mathematics activity: Viewing transformation during the middle school years. Multicultural Education, 17(2), 2-12.

Roos, E. (2019). Inclusion in mathematics education: an ideology, a way of teaching, or both? Educational Studies in Mathematics, 100(1), 25-41.

Schmidt, M. C. S. (2016). Inclusion in mathematics education: an ideology, a way of teaching, or both? Cursiv, 18, 81-105.

Seah, W. T., \& Andersson, A. (2015). Valuing diversity in mathematics pedagogy through the volitional nature and alignment of values. In A. Bishop, H. Tan, \& T. N. Barkatsas (Eds.), Diversity in mathematics education: Towards inclusive practices (pp. 167-184). Cham: Springer.

Šíp, R. (2019). Proč školství a jeho aktérí selhávají. Kognitivni krajiny a nacionalismus [Why education and its actors are failing. Cognitive landscapes and nationalism]. Brno: Masaryk University.

Vithal, R. (2003). In search of a pedagogy of conflict and dialogue for mathematics education. Dordrecht: Kluwer.

Vithal, R., \& Valero, P. (2003). Researching mathematics education in situations of social and political conflict. In A. J. Bishop, M. A. Clements, C. Keitel, J. Kilpatrick, \& F. K. S. Leung (Eds.), Second international handbook of mathematics education (pp. 545-593). Dordrecht: Kluwer. 
Wilson, L. S. (1992). The benefits of diversity in the science and engineering work force. In M. L. Matyas \& L. S. Dix (Eds.), Science and engineering programs: On target for women? (pp. 1-14). Washington, DC: National Academy Press.

Ioannis Papadopoulos

School of Primary Education, Faculty of Education, Aristotle University of Thessaloniki, Greece, and Charles University, Czech Republic;

e-mail:ypapadop@eled.auth.gr

Darina Jirotková

Department of Mathematics and Mathematical Education, Faculty of Education, Charles University, Czech Republic

Jana Slezáková

Department of Mathematics and Mathematical Education, Faculty of Education, Charles University, Czech Republic

Esperanza López Centella

Department of Didactics of Mathematics, Faculty of Education Sciences, University of Granada, Spain, and Charles University, Czech Republic

\section{PAPADOPOULOS, I., JIROTKOVÁ, D., SLEZÁKOVÁ, J., LÓPEZ CENTELLA, E. Aktuální změny v primárním vzdělávání: Problematika „odlišnosti“ ve třídě při výuce matematiky na prvním stupni základní školy}

$V$ podminkách, kdy se naše společnost transformuje na multikulturni, chceme $v$ tomto príspèvku zkoumat situace $v$ hodinách matematiky ve třidè, kde koexistuje respekt a odmitnutí „odlišnosti“. V prípadové studii sledujeme dvě skupiny žáku 4. ročníku prì rèseni úlohy cílené na zobecnèni matematického vztahu. Zkoumáme, jak interakce mezi členy skupin odráži dvě strany stejné mince, kterou je kultura tř́dy, a zároveň jak odráži zmèny ve trúdè, které vyžaduji otevrenost a upřimný respekt $k$ „odlišnosti “. Na jedné straně predvedeme dynamiku souznèní, které bylo patrné mezi členy jedné ze skupin, protože „odlišnost“ nebyla překážkou, ale naopak byla zdrojem matematických myšlenek, které prìspèly $k$ rèseni. Na druhé straně ukážeme, jak nedostatek otevřenosti u druhé skupiny vedl k promarněni 
dobrých príležitostí pro "děláni matematiky" a $k$ ohroženi sebevědomi jednoho z jejich členü.

Klićová slova: rozmanitost ve trídè a konflikt, matematika v multikulturni trídè, spolupráce na řešeni problému 